\title{
A Numerical Study to Precise the Estimation of the "Good" Mound Height in Endoscopic Treatment of VUR
}

\author{
Mehdi Shirazi' ${ }^{1}$, Zahra Jahanabadi' ${ }^{1}$ Zeinab Hooshyar ${ }^{2}$, Zahra Mortazavinia ${ }^{3}$, \\ Alireza Mehdizadeh ${ }^{4}$, Mojtaba Taherisadr ${ }^{5}$ \\ ${ }^{1}$ Urology Department, Shiraz University of Medical Science, Shiraz, Iran \\ ${ }^{2}$ Mechanical Engineering, Shiraz University, Shiraz, Iran \\ ${ }^{3}$ École Polytechnique de Montréal, Mechanical Engineering Department, Montreal, Canada \\ ${ }^{4}$ Shiraz University of Medical Science (SUMS), Shiraz, Iran \\ ${ }^{5}$ Biomedical Engineering Department, Isfahan University, Esfahan, Iran \\ Email: ${ }^{*}$ mehdizade@sums.ac.ir
}

Received 19 July 2014; revised 4 September 2014; accepted 19 September 2014

Copyright (C) 2014 by authors and Scientific Research Publishing Inc.

This work is licensed under the Creative Commons Attribution International License (CC BY). http://creativecommons.org/licenses/by/4.0/

(c) (i) Open Access

\begin{abstract}
Objective: To ascertain the technique and volume of injection increasing the success rate of endoscopic VUR treatment, we develop a novel method to numerically describe the relationship between intramural ureter anatomy, intravesical pressure, and the theoretical mound height needed for adequate treatment. Methods: The main purpose of this study is to construct a finite element simulation of intramural ureter and injected mound which aims to numerically define the relationship between indexes which have influence in VUR endoscopic treatment. Using linearization software and numerically simulation data, the relationship between effective indexes has been derived. Results: By linearization of the effective parameters of different finite element models, the relationship between effective parameters in filling phase is derived as: $H(\mathrm{~m})=\mathbf{- 0 . 0 0 3 4 6 7}(\mathrm{m})$ $+0.7864 D(\mathrm{~m})+0.000233$. This equation depicts adequate injected mound height as a function of internal diameter and intramural length, $H=f(L, D)$. Conclusion: Using numerical simulation, we introduced the novel formula to predict the height of injected mound in endoscopic VUR treatment. As a result of this study, in order to increasing the success rate of this treatment, the ratio of mound height to intramural ureter diameter should be approximately $78 \%$.
\end{abstract}

\section{Keywords}

Mound Height, Endoscopic Treatment, Vesico Ureteral Reflux, Numerical Simulation

\footnotetext{
${ }^{*}$ Corresponding author.

How to cite this paper: Shirazi, M., Jahanabadi, Z., Hooshyar, Z., Mortazavinia, Z., Mehdizadeh, A. and Taherisadr, M. (2014) A Numerical Study to Precise the Estimation of the "Good" Mound Height in Endoscopic Treatment of VUR. J. Biomedical Science and Engineering, 7, 941-947. http://dx.doi.org/10.4236/jbise.2014.711091
} 


\section{Introduction}

Vesico ureteral reflux (VUR) is a major disorder of childhood declared by retrograde urine flow from the bladder toward the kidney, predisposing patients to UTI and renal scarring and in long term leading to renal insufficiency and hypertension [1]. Current treatment options include close observation with urinary chemoprophylaxis, minimally invasive endoscopic subureteral injection of bulking agents and open or laparoscopic reimplantation [2]. The prophylactic antibiotic approach is proper for uncomplicated reflux (grade I-III without significant renal scarring or breakthrough infection) [3]. This type of treatment has some problems such as patient noncompliance and increased antibiotic resistance [4].

Surgical reimplantation of the ureter is an invasive method [5] and already used for patients with high grade reflux, children with breakthrough UTI and children with reflux and developed renal scarring [6]. Endoscopic subureteral injection of bulking agents was introduced by Matouscheck as an evolution in treatment of reflux with a high success rate and minimal invasion [6] [7]. The substance used as a bulking material should be biocompatible, non-antigenic, non-migratory and non-toxic with minimal local inflammation [8]. Multiple techniques on injection have been described. These methods include sub-ureteral needle placement [8], intra-ureteral needle placement [9] [10] or some combinations of these. During recent years, several studies have been done to determine the success or failure of endoscopic treatment, and various injection techniques have been introduced. Puri et al. described "volcano" appearance as the main sign of success of injection [11]. The proper shape was demonstrated by adequate coaptation of the ureteral orifice and by its location in the bladder below the ureteral orifice and/or along the waldeyer's sheat [12] [13].

Despite all the studies carried out to determine the success or failure of endoscopic treatment, such as description of volcano appearance, injection technique in combination with hydroidstention, increasing injected volume, use of intraoperative cystogram with a simulated voiding phase, there is no definite and standard index to ascertain the technique and volume of injection in order to increase the success rate. The aim of this study is to develop a novel method to numerically describe the relationship between intramural ureter anatomy, intravesical pressure, and the theoretical mound height needed for adequate treatment.

\section{Materials \& Method}

In this study, a computational simulation for children aged between 2.5 to 10.5 years was proposed to simulate the intramural ureter and injected mound which aims to numerically define the relationship between indexes which influence the retrograde urine flow from the intramural ureter in voiding phase.

\subsection{Geometry of the Numerical Model}

Figure 1 illustrates diagrammatic representation of the functional anatomy of the ureterovesical junction and urinary anti-reflux mechanism as the accumulation of urine within the bladder will lead to the tight closure of the portion of the ureter in between, thus preventing the backward return of urine to the kidneys, urinary antireflux mechanism. In Figure 1, P, D, H and L are intravesical pressure, intramural ureter diameter, injected mound height, and intramural ureter length, respectively. Section "A" in Figure 1 depicts the cross section of the intramural ureter with injected mound. The geometrical data of the intramural ureter and ureterovesical junction for children aged between 2.5 to 10.5 years were utilized as per Table 1.

\subsection{Materials Properties and Boundary Conditions}

Material properties for the intramural ureter wall were assumed to be linear elastic, isotropic, incompressible, and homogeneous with Young's modulus of $5 \mathrm{kpa}$ [18]. In reality, the deflux mound often pushes up the ureter in volcano type appearance, so the injected mound was considered as a rigid hemispherical volumeat the beginning of the intramural ureter to provide more similarity to the real shape. The boundary conditions for the wall were the bottom half surface of the intramural external wall which was fixed at the connection to the internal bladder wall. However, the upper half surface wall was assumed to be free so that the deformation would occur due to the intravesical pressure and contribute to the tight closure of the portion of the ureter.

\subsection{Solution Method}

The ANSYS 11 software was employed to simulate the intramural ureter with injected mound in voiding phase. 
Table 1. Geometrical data of intramural ureter and ureterovesical junction.

\begin{tabular}{ccccc}
\hline $\begin{array}{c}\text { Children Intravesical } \\
\text { Pressure }\left(\mathrm{CmH}_{2} \mathrm{O}\right)\end{array}$ & $\begin{array}{c}\text { Intramural Ureter } \\
\text { Diameter }(\mathrm{mm})\end{array}$ & $\begin{array}{c}\text { Intramural Wall } \\
\text { Thickness (mm) }\end{array}$ & $\begin{array}{c}\text { Intramural } \\
\text { Length (mm) }\end{array}$ & $\begin{array}{c}\text { Inlet-Outlet Connector } \\
\text { Line Angle }\end{array}$ \\
\hline $\begin{array}{c}\text { Resting: } 6.2[14] \text { - Voiding: } 86 \\
\text { (Female)/160 (Male) [15] }\end{array}$ & $1.2-2[16]$ & $0.95[17]$ & 10 & 17 \\
\hline
\end{tabular}
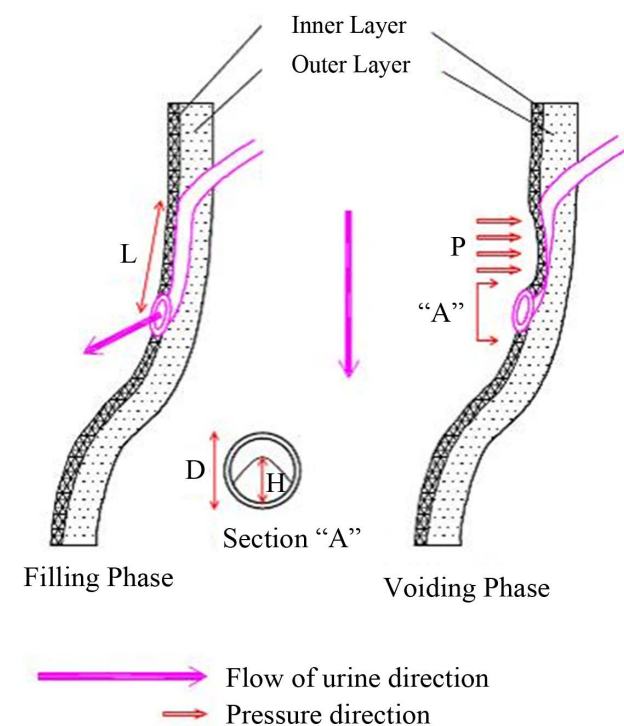

Figure 1. Diagrammatic representation of the functional anatomy of the ureterovesical junction.

The intravesical pressure was applied on the upper portion of the intramural wall. The upper bound of intravesical pressure was considered to be $160 \mathrm{~cm} \mathrm{H}_{2} \mathrm{O}$ to encompass both male and female intravesical voiding pressures [15], see Table 1. The 8-node shell and structural solid element type were utilized for intramural wall and mound meshing, respectively to provide adequate adoption with their geometry and material behavior.

\section{Results}

Figure 2 illustrates the total deformation of the intramural ureter with injected mound in voiding phase obtained by finite element modeling. As shown, in voiding position the injected mound height is high enough for the intramural ureter to be closed due to the intravesical pressure and prevents retrograde urine flow. Figure 3 shows this procedure schematically.

Keeping the intramural ureter length constant by changing the intravesical pressure and internal diameter parameters, the adequate injected mound height leading to tight closure of the intramural ureter was obtained.

Using linearization technique in Excel Software, the relationship between injected mound height, intravesical pressure and internal diameter of the intramural ureter parameters was defined as bellow, $H=f(D, P)$

$$
H(\mathrm{~m})=-0.0000003219 P(\mathrm{~Pa})+0.7864 D(\mathrm{~m})+0.000233
$$

In some cases, the intramural length should be considered as one of effective indexes in the injected mound height, so this parameter should be investigated as one of variable parameters in the defined formula. According to the physics law, the pressure of liquid is:

$$
P=\rho \times g \times h
$$

where $\rho, g, h$ are urine specific gravity, gravity acceleration and liquid height, respectively. Substituting this formula in Equation (1), and considering $\rho=1050 \mathrm{~kg} / \mathrm{m}^{3}$ [18], $g=9.81 \mathrm{~m} / \mathrm{s}^{2}$ and Inlet-Outlet Connector line angle $=17$, the relationship between internal diameter, intramural length and optimum mound height was derived as: 


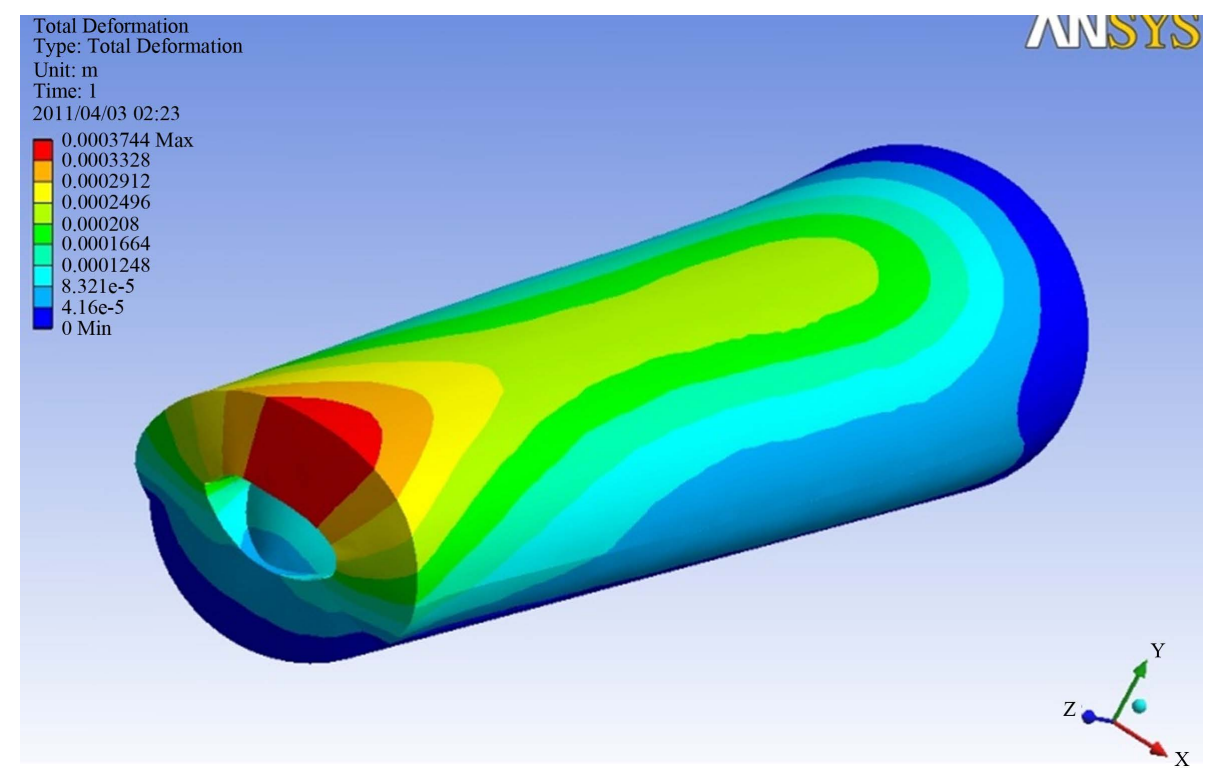

Figure 2. Intramural ureter displacement in voiding phase.

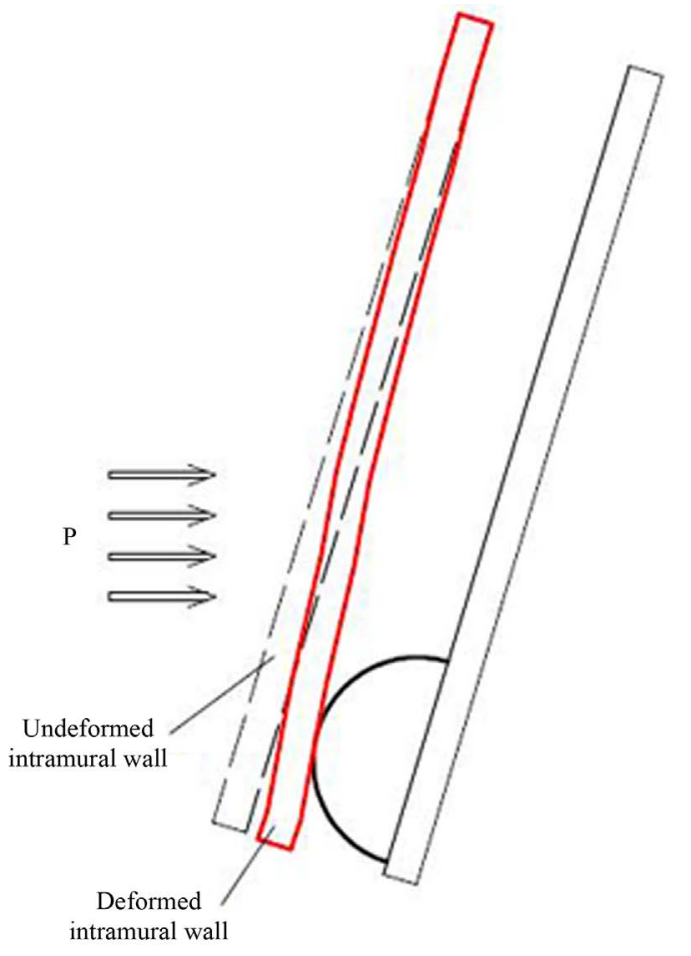

Figure 3. Deformed and undeformed intramural urine wall.

$$
H(\mathrm{~m})=-0.003467(\mathrm{~m})+0.7864 D(\mathrm{~m})+0.000233
$$

This equation depicts optimum mound height as a function of internal diameter and intramural length, $H=f(L, D)$.

\section{Discussion}

Endoscopic treatment of VUR was introduced more than 25 years ago and since then many different substances and injection techniques have been used with different results [13]. Choosing endoscopic treatment is reasona- 
ble, as it has many advantages, such as technical simplicity, greater acceptance of patients and parents and a significant decrease in post-operation complications [7]. By improving the injection techniques, the rate of endoscopic treatment has significantly increased as compared with open ureteral reimplantation [2]. During the recent years, many studies have been done to increase the ability to identify factors predicting success with the endoscopic subureteral injection [19]. At 2003, Puri et al. [11] described "volcano" appearance as the main sign of success of injection. The proper shape was demonstrated by adequate coaptation of the ureteral orifice and by its location in the bladder below the ureteral orifice and/or along the waldeyer's sheat [12].

In different studies conducted by Lavelle et al. [12] and Yucel et al. [20], it was found that a subjectively proper mound appearance was highly predictive of injection success, but it should be noted that the morphology and location of the mound are not perfectly predictive of injection success or failure, as the mound seems perfectly adequate in some injections but the injection is not successful; also, the imperfect mound morphology does not necessarily imply injection failure [12]. Moreover, Ellworth PI et al. showed no correlation between the presence of a mound on the post-injection ultrasound and the success of injection [19]. Some research indicated that an intraureteral injection technique in combination with hydrodistention results in higher success rates but this is controversial [9] [10] [20] [21]. The effect of injected volume on increasing the success rate is also controversial. Mathew et al. showed that increasing the injection material volume will improve the success of subureteric injection [22] but other centers have shown that higher injection material volume does not necessarily increase the treatment success rate [21]. So, the effect of the injected volume in association with improved success rate remains unclear [12].

To determine the treatment success or failure, Tarry et al. described the utility of an intraoperative cystogram with a simulated voiding phase, but they demonstrated that an introperative cystogram can only detect de novo contralateral reflux but is not a proper method to predict the final success of injection [6]. Despite all the mentioned studies, still there is no definite and standard index to ascertain the technique and volume of injection, and also there is no quantitative index for determining the proper mound size and shape. So, we have conducted a study aiming to define an optimum injection mound by finite element modeling.

In this study, we numerically defined the relationship between some indexes in order to determine optimum mound height promise to standardize the injection technique in VUR treatment. It should be noted that due to every patient's individual properties of intramural, it is not logical to consider similar injected mound height for all VUR treatment cases. Thus, it is needed to state the adequate injected mound height based on individual indexes of each case. The intravesical pressure, intramural ureter diameter and length are some of these effective indexes. By specifying the relationship between all of these effective factors, the adequate and optimum injected mound height can be determined which can contribute to more success in treatment of VUR. In addition, it can help to save the needed injected mound height and make this injection method more economical.

The results of this study show that the ratio of mound height tointramural ureter diameter is approximately 0.78 , which is drawn. In order to have successful VUR treatment, it is necessary to fill about $78 \%$ of the intramural ureter diameter with the injected mound. It should be mentioned that in Department of Urology of Shiraz University for the first time, an innovative method, introduced by Taheri et al. [23] is used to measure the injected mound height to assure adequate injected mound height practically. In this method by adjusting camera, laparoscopy lens and imaging screen, it would be possible to measure the injected mound height as a ratio of projected picture on the screen.

This study has some limitations. First, the realistic cross section of the intramural ureter hasa star shape. However, because of some limitations in finite element modeling, the circular one was considered. Second, we considered computational simulation only in voiding phase, although VUR may occur in resting phase. Third, the Young's modulus of the intramural ureter wall is cited with different values in some references [18] [24] [25]; the $E=5 \mathrm{kpa}$ was considered in this study. The last but not the least, this study is preliminary, so further clinical studies are recommended to be conducted to ascertain the accuracy of this obtained height.

\section{Conclusion}

In this study using numerical simulation, we developed a novel formula to predict the height of the injected mound in endoscopic VUR treatment. As a result of this study, in order to increase the success rate of this technique, the ratio of mound height to the intramural ureterdiameter should be approximately $78 \%$. However, more clinical studies were recommended to be conducted to ascertain the accuracy of this obtained height. 


\section{References}

[1] Lenaghan, D., et al. (1976) The Natural History of Reflux and Long-Term Effects of Reflux on the Kidney. Journal of Urology, 115, 728-730. http://dx.doi.org/10.2214/AJR.09.3790

[2] Cerwinka, W.H., et al. (2010) Radiologic Features of Implants after Endoscopic Treatment of Vesicoureteral Reflux in Children. American Journal of Roentgenology, 195, 234-240. http://dx.doi.org/10.1089/lap.2007.0256

[3] Harper, L., et al. (2008) Postoperative Cystography and Endoscopic Treatment of Low-Grade Vesicoureteral Reflux. Journal of Laparoendoscopic and Advanced Surgical Techniques, 18, 461-463. http://dx.doi.org/10.1016/j.urology.2009.10.034

[4] Hsieh, M.H., et al. (2010) Treatment of Pediatric Vesicoureteral Reflux Using Endoscopic Injection of Hyaluronic Acid/ Dextranomer Gel: Intermediate-Term Experience by a Single Surgeon. Urology, 76, 199-203.

[5] Elder, J.S., et al. (1997) Pediatric Vesicoureteral Reflux Guidelines Panel Summary Report on the Management of Primary Vesicoureteral Reflux in Children. The Journal of Urology, 157, 1846-1851. http://dx.doi.org/10.1016/S0022-5347(01)64882-1

[6] Perlmutter, A.E., et al. (2008) Utility of an Intra-Operative Cystogram with a Simulated Voiding Phase after Endoscopic Treatment of Vesicoureteral Reflux. The West Virginia Medical Journal, 104, 22-24.

[7] Rivilla, F. (2011) Endoscopic Treatment of Vesicoureteral Reflux in a Paediatric Surgery Ambulatory Unit. Journal of Minimal Access Surgery, 7, 132-135.

[8] Bae, Y.D., et al. (2010) Endoscopic Subureteral Injection for the Treatment of Vesicoureteral Reflux in Children: Polydimethylsiloxane (Macroplastique ${ }^{\circledR}$ ) versus Dextranomer/Hyaluronic Acid Copolymer (Deflux ${ }^{\circledR}$ ). Korean Journal of Urology, 51, 128-131. http://dx.doi.org/10.4111/kju.2010.51.2.128

[9] Gupta, A. and Snodgrass, W. (2008) Intra-Orifice versus Hydrodistention Implantation Technique in Dextranomer/ Hyaluronic Acid Injection for Vesicoureteral Reflux. The Journal of Urology, 180, 1589-1593. http://dx.doi.org/10.1016/j.juro.2008.04.073

[10] Kirsch, A.J., et al. (2004) The Modified Sting Procedure to Correct Vesicoureteral Reflux: Improved Results with Submucosal Implantation within the Intramural Ureter. The Journal of Urology, 171, 2413-2416. http://dx.doi.org/10.1097/01.ju.0000127754.79866.7f

[11] Puri, P., Chertin, B., Velayudham, M., Dass, L. and Colhoun, E. (2003) Treatment of Vesicoureteral Reflux by Endoscopic Injection of Dextranomer/Hyaluronic Acid Copolymer: Preliminary Results. The Journal of Urology, 170, 15411544. http://dx.doi.org/10.1097/01.ju.0000083924.44779.80

[12] Routh, J.C. and Reinberg, Y. (2010) Predicting Success in the Endoscopic Management of Pediatric Vesicoureteral Reflux. Urology, 76, 195-198. http://dx.doi.org/10.1016/j.urology.2009.09.017

[13] Lavelle, M.T., Conlin, M.J. and Skoog, S.J. (2005) Subureteral Injection of Deflux for Correction of Reflux: Analysis of Factors Predicting Success. Urology, 65, 564-567. http://dx.doi.org/10.1016/j.urology.2004.09.068

[14] Yeung, C.K., Godley, M.L., Duffy, P.G. and Ransley, P.G. (1995) Natural Filling Cystometry in Infants and Children. British Journal of Urology, 31, 213.

[15] Yeung, C.K., Godley, M.L., Dhillon, H.K., Duffy, P.G., et al. (1998) Urodynamic Patterns in Infants with Normal Lower Urinary Tracts or Primary Vesico-Ureteric Reflux. British Journal of Urology, 81, 461-467. http://dx.doi.org/10.1046/j.1464-410x.1998.00567.x

[16] Ellsworth, P.I., Cendron, M. and McCullough, M.F. (2000) Surgical Management of Vesicoureteral Reflux. AORN Journal, 71, 496-513. http://dx.doi.org/10.1016/S0001-2092(06)61573-1

[17] Wolf Jr., J.S., Humphrey, P.A., Rayala, H.J., Gardner, S.M., Mackey, R.B. and Clayman, R.V. (1996) Comparative Ureteral Microanatomy. Journal of Endourology, 10, 527-531. http://dx.doi.org/10.1089/end.1996.10.527

[18] Vahidi, B. and Fatouraee, N. (2012) A Biomechanical Simulation of Ureteral Flow during Peristalsis Using Intraluminal Morphometric Data. Journal of Theoretical Biology, 298, 42-50. http://dx.doi.org/10.1016/j.jtbi.2011.12.019

[19] Ellsworth, P.I., Yates, J.K. and Caldamone, A.A. (2011) Presence of Dextranomer-Hyaluronic Acid (DxHA) Mound on Postoperative Ultrasound Does Not Predict Resolution of Vesicoureteral Reflux. Journal of Pediatric Urology, 7, 438-440. http://dx.doi.org/10.1016/j.jpurol.2010.05.008

[20] Yucel, S., Gupta, A. and Snodgrass, W. (2007) Multivariate Analysis of Factors Predicting Success with Dextranomer/ Hyaluronic Acid Injection for Vesicoureteral Reflux. The Journal of Urology, 177, 1505-1509. http://dx.doi.org/10.1016/j.juro.2006.11.077

[21] Routh, J.C., Reinberg, Y., Ashley, R.A., Inman, B.A., Wolpert, J.J., Vandersteen, D.R., Husmann, D.A. and Kramer, S.A. (2007) Multivariate Comparison of the Efficacy of Intraureteral versus Subtrigonal Techniques of Dextranomer/Hyaluronic Acid Injection. The Journal of Urology, 178, 1702-1706. 
http://dx.doi.org/10.1016/j.juro.2007.03.174

[22] Sorensen, M., Koyle, M.A., Cowan, C.A., Zamilpa, I., Shnorhavorian, M. and Lendvay, T.S. (2010) Injection Volumes of Dextranomer/Hyaluronic Acid Are Increasing in the Endoscopic Management of Vesicoureteral Reflux. Pediatric Surgery International, 26, 509-513. http://dx.doi.org/10.1007/s00383-010-2558-9

[23] Taheri Sadr, M., Karami, N. and Shirazi, M. (2012) A Novel Method for Measuring, Regardless of Image Distortion and Lens Varying Specifications in Endoscopic Treatment of Vesicoureteral Reflux. Journal of Biomedical Physics and Engineering, 2, 120-122.

[24] Lee, J.W., Lorenzo, E.I., Ahn, B., Oh, C.K., Kim, H.J., Han, W.K., Kim, J. and Rha, K.H. (2011) Palpation Device for the Identification of Kidney and Bladder Cancer: A Pilot Study. Yonsei Medical Journal, 52, 768-772.

[25] Dahms, S.E., Piechota, H.J., Dahiya, R., Lue, T.F. and Tanagho, E.A. (1998) Composition and Biomechanical Properties of the Bladder Acellular Matrix Graft: Comparative Analysis in Rat, Pig and Human. British Journal of Urology, 82, 411-419. http://dx.doi.org/10.1046/j.1464-410X.1998.00748.x 
Scientific Research Publishing (SCIRP) is one of the largest Open Access journal publishers. It is currently publishing more than 200 open access, online, peer-reviewed journals covering a wide range of academic disciplines. SCIRP serves the worldwide academic communities and contributes to the progress and application of science with its publication.

Other selected journals from SCIRP are listed as below. Submit your manuscript to us via either submit@scirp.org or Online Submission Portal.
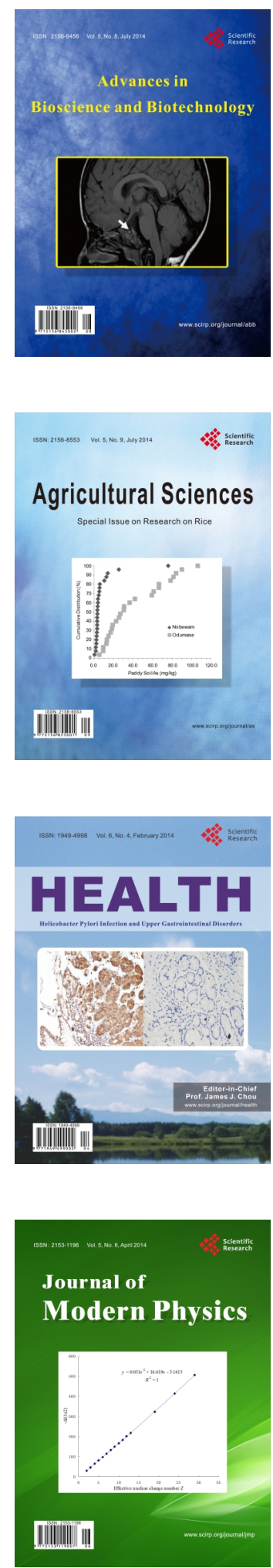
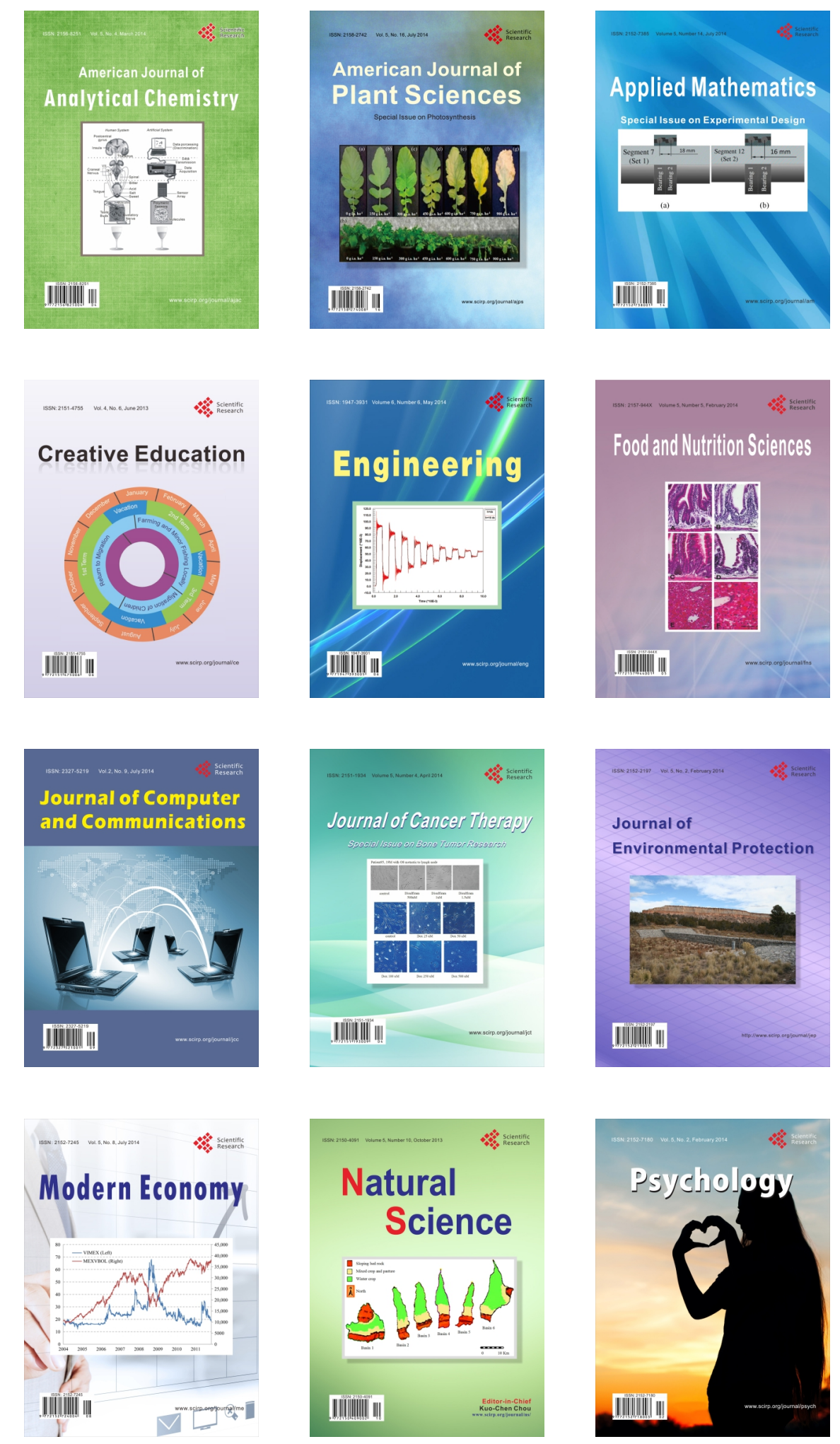